\title{
How strong is the relationship between rainfall variability and Caatinga productivity? A case study under a changing climate
}

\author{
CLEBER SALIMON ${ }^{1}$ and LIANA ANDERSON ${ }^{2}$ \\ ${ }^{1}$ Universidade Estadual da Paraíba, Rua Horácio Trajano, s/n, 58071-160 João Pessoa, PB, Brazil \\ ${ }^{2}$ Centro Nacional de Monitoramento de Desastres Naturais, Estrada Doutor Altino Bondesan, \\ 500, Distrito de Eugênio de Melo, 12247-016 São José dos Campos, SP, Brazil
}

Manuscript received on February 23, 2017; accepted for publication on February 23, 2017

\begin{abstract}
Despite the knowledge of the influence of rainfall on vegetation dynamics in semiarid tropical Brazil, few studies address and explore quantitatively the various aspects of this relationship. Moreover, Northeast Brazil is expected to have its rainfall reduced by as much as $60 \%$ until the end of the $21^{\text {st }}$ Century, under scenario AII of the IPCC Report 2010. We sampled and analyzed satellite-derived monthly rainfall and a vegetation index data for 40 sites with natural vegetation cover in Paraíba State, Brazil from 2001 to 2012. In addition, the anomalies for both variables were calculated. Rainfall variation explained as much as $50 \%$ of plant productivity, using the vegetation index as a proxy, and rainfall anomaly explained $80 \%$ of the vegetation productivity anomaly. In an extreme dry year (2012), with $65 \%$ less rainfall than average for the period 2001-2012, the vegetation index decreased by $25 \%$. If such decrease persists in a long term trend in rainfall reduction, this could lead to a disruption in this ecosystem functioning and the dominant vegetation could become even more xeric or desert-like, bringing serious environmental, social and economical impacts.
\end{abstract}

Key words: Paraíba, rainfall anomaly, ecosystem productivity, semiarid, vegetation index.

\section{INTRODUCTION}

Rainfall is one of the most important drivers of ecosystem dynamics and productivity (i.e. Weltzin et al. 2003). Nevertheless, studies analysing the impact of extreme climate on Brazilian ecosystems are scarce and, of these, most regard the Amazon Forest (i.e. Anderson et al. 2010, Saatchi et al. 2013). In semiarid Caatinga, a few studies have

Correspondence to: Cleber Salimon

E-mail: clebsal@ccbsa.uepb.edu.br

* Contribution to the centenary of the Brazilian Academy of Sciences. addressed the issue and have shown a trend of enhanced aridity over the last decades (Barbosa et al. 2006) and a tendency of rainfall reduction in the future, according to 23 climatic models developed by the Intergovernmental Panel on Climate Change (IPCC), under A1B scenario (Malhi et al. 2008).

In the past, Northeast Brazil was under wetter climates, as suggested by geological, geomorphological and ocean sediment data (Arz et al. 1998, Auler and Smart 2001). These wet periods have been associated with the southward displacement of the Intertropical Convergence 
Zone (Wang et al. 2004). Today, Northeast Brazil is a drought-prone semi-arid region, with high rainfall variability, characterized by xeric shrubland (savanna) and sparse forests of deciduous thorny trees (dry forests). The semi-arid region is suffering a major drought since 2012 (Pereira et al. 2014), claimed to be the worst drought in 30 years (Novaes et al. 2013).

Modelling studies suggest that the Caatinga ecosystems return about $75 \%$ of the annual rainfall to the atmosphere (Pinheiro et al. 2016). Although it has been suggested that dry region vegetation shows resilience after prolonged drought periods (Campos et al. 2013, Donohue et al. 2013), the 2012 drought strongly influenced net primary production in the Caatinga, reducing its annual net ecosystem exchange (Pereira et al. 2014). Gross and Net Ecosystem Productivity (GEP and NEP) are usually measured directly with a variety of equipments and techniques, mostly using eddy covariance towers and infrared gas analysers; demanding heavy infrastructure and long term field campaigns (Ran et al. 2016). The use of remote sensing data allows researchers to survey large areas with a moderately large temporal and spatial resolution at relatively low cost and comparatively little time consumption. One of such indirect approaches to address NEP is the use of vegetation indices, which are a proxy for leaf area index (LAI). Vegetation indices also seem to respond clearly to severe droughts (Wagle et al. 2014). In tropical savannas, the Enhanced Vegetation Index (EVI) is correlated to ground measurements of GEP (Xuanlong et al. 2013).

Although Caatinga vegetation is driven by low rainfall with low productivity and biomass, they vary greatly spatially and temporally (Erasmi et al. 2014). At the same time, Northeast semiarid Brazil is populated by more than 20.5 million inhabitants (INSA 2012), who depend on this biomass production, livestock and water availability in this region, which encompasses almost $11 \%$ of the Brazilian territory. Due to these characteristics (low ecosystem productivity and great human population), it is important to understand the variability and vulnerability of Caatinga production to climatic anomalies, mainly in the light of predicted scenarios of $60 \%$ rainfall reduction until the end of the $21^{\text {st }}$ (scenario AII, IPCC, Marengo et al. 2009).

In this study we focus in the state of Paraíba; which has some of the lowest rainfall records in Northeast Brazil. This study aims to quantify the relationship between the rainfall anomalies and ecosystem productivity. To empirically and quantitatively test it, we analysed rainfall data and remote sensing derived vegetation index as a proxy for NEP. Then, we estimated the vegetation resistance to severe drought events by correlating rainfall anomalies with vegetation index anomalies. Specifically, we (1) estimated the time lag between rainfall events and vegetation response; (2) determined locally the correlation between the vegetation index and rainfall; (3) calculated rainfall and vegetation index anomalies; and (4) estimated how much of the vegetation index anomaly correlates with rainfall anomaly.

\section{MATERIALS AND METHODS}

We use the Enhanced Vegetation Index (EVI-2) in this paper due to (1) its ease of access (EVI-2 data directly extracted from the National Institute for Space Research [INPE]); (2) response to rainfall (Wagle et al. 2014); and (3) significant correlation with GEP (Xuanlong et al. 2013). Since the aim of this paper is not the index per se, but its relationship with rainfall anomalies in semiarid ecosystems, details for the remote sensing techniques and methods are provided elsewhere (Jiang et al. 2008, Freitas et al. 2011). We assumed that since we are using one time-series of vegetation index derived from the same sensor, all inherent and probable biases and errors are systematically and equally distributed to all sites. 
This study encompasses a time series from 2001 to 2012. Although not a long historic series, this period encompasses both rainy and very dry years, therefore representing well interannual rainfall patterns for the region. Data for the modified Enhanced Vegetation Index (EVI-2; Jiang et al. 2008, Huete et al. 2002) and rainfall from the Tropical Rainfall Measuring Mission (TRMM) available from NASA, were both extracted and downloaded from INPE's website (https://www.dsr.inpe.br/laf/series/). We sampled 40 randomly selected points from 4 municipalities, by overlapping a point grid on Paraíba State under Google Earth Pro environment. Each point on the grid was at least $500 \mathrm{~m}$ away from each other. After random selection, each point was checked by visual inspection in high resolution imagery at viewing point altitude of $1000 \mathrm{~m}$ to ensure that the site was covered by natural vegetation. If the location of the random point coincided with a clear-cut area, the closest grid point with natural vegetation was selected. For each of the 40 points (Figure 1), latitude and longitude were used to extract EVI-2 and rainfall data. The EVI-2 data referred to a 15day composite, while the rainfall data presented a monthly time-step. In order to generate the monthly EVI-2, the average per pixel was calculated.
Historic series for the 40 points. Each point refers to the monthly data from 2001 to 2012, summing 144 months. The EVI refers to the monthly average between two measurements, while rainfall refers to the monthly cumulative data. These data were then organized and statistically analysed.

To test the time lag for all 40 points, we regressed monthly rainfall with EVI data of the previous, same, $+1,+2$ and +3 months to check which showed the highest regression coefficient $\left(r^{2}\right)$. The $r^{2}$ for these regressions were tested for significance by the Kruskal Wallis test. For all other objectives, we ran linear regression models, in $\mathrm{R}$ environment (R Development Core Team 2008).

To estimate interannual variation of both rainfall and EVI, we used an Anomaly index (z-score), which is a measure of how much different each year is in relation to the studied period's average (1):

$$
\mathrm{zi}=(\mathrm{Vi}-\mathrm{Xi}) / \mathrm{Xi}
$$

where: zi (i anomaly); Vi (i value); Xi (i average).

\section{RESULTS AND DISCUSSION}

Rainfall data for all 40 sites, from 2001 to 2012, showed an annual average of $881 \pm 160 \mathrm{~mm}$

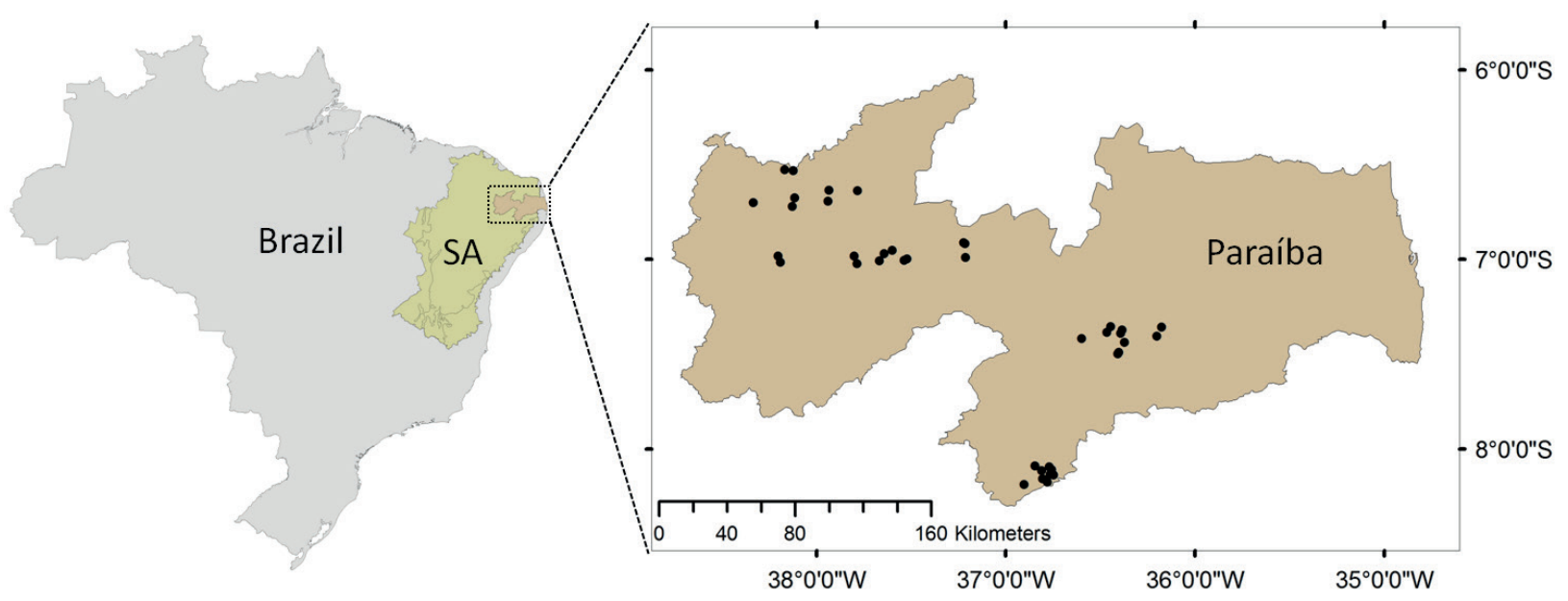

Figure 1 - The semiarid (SA) region of Northeast Brazil and Paraíba state with the 40 target points selected for this study. 
(maximum=1,670 $\mathrm{mm}$; minimum=238 mm). For all sites, November had the lowest rainfall, with an average of $6 \mathrm{~mm}$, and February the highest one, with an average of $139 \mathrm{~mm}$ (Figure 2). EVI data for the 40 sites had an annual average (2001-2012) of $0.286 \pm 0.043$ (maximum $=0.75$; minimum $=0.15$ ) November having the smallest EVI, with an average of 0.18 , and February the highest one, with an average of 0.43 (Figure 2). A table with all data and numerical results is available as a Supplementary Material (Table SI).

A seasonal one month phase lag in the response of vegetation to rainfall was observed for all sites $(\mathrm{p}<0.001 ; \mathrm{n}=40)$, the same lag reported for the whole Northeast region (Schucknecht et al. 2012). Probably, the actual vegetation response is a little shorter than one month, but since we used the TRMM monthly rainfall data, this was the best fit obtainable. Therefore, all analyses hereafter were made using a one month lag for EVI-2.
CORRELATIONS BETWEEN RAINFALL AND ECOSYSTEM PRODUCTIVITY (EVI)

All 40 individual correlations between rainfall and EVI were statistically significant $(p<0.001$; $\mathrm{n}=144$ ). The average individual correlation was $r^{2}=0.47 \pm 0.12(\max =0.68 ; \min =0.22)$. When we averaged annual data of all 40 points for both rainfall and EVI, we found a marginally significant relationship between rainfall and EVI $\left(; r^{2}=0.32\right.$; $p=0.08 ; n=40$ ), showing that on an annual and at the landscape scale, higher annual rainfall also implies in a larger ecosystem productivity. For the average monthly data of all 40 points rainfall variation explained as much as $68 \%$ of EVI (Figure 3 ).

All these results, from local to landscape scale, show at different degrees ( $\mathrm{r}^{2}$ from 0.47 to 0.68$)$ the same pattern: ecosystem productivity of Caatinga vegetation is closely linked to rainfall variation. Schucknecht et al. (2012), using EVI, and Becerra et al. (2015), using NDVI, found similar relationships

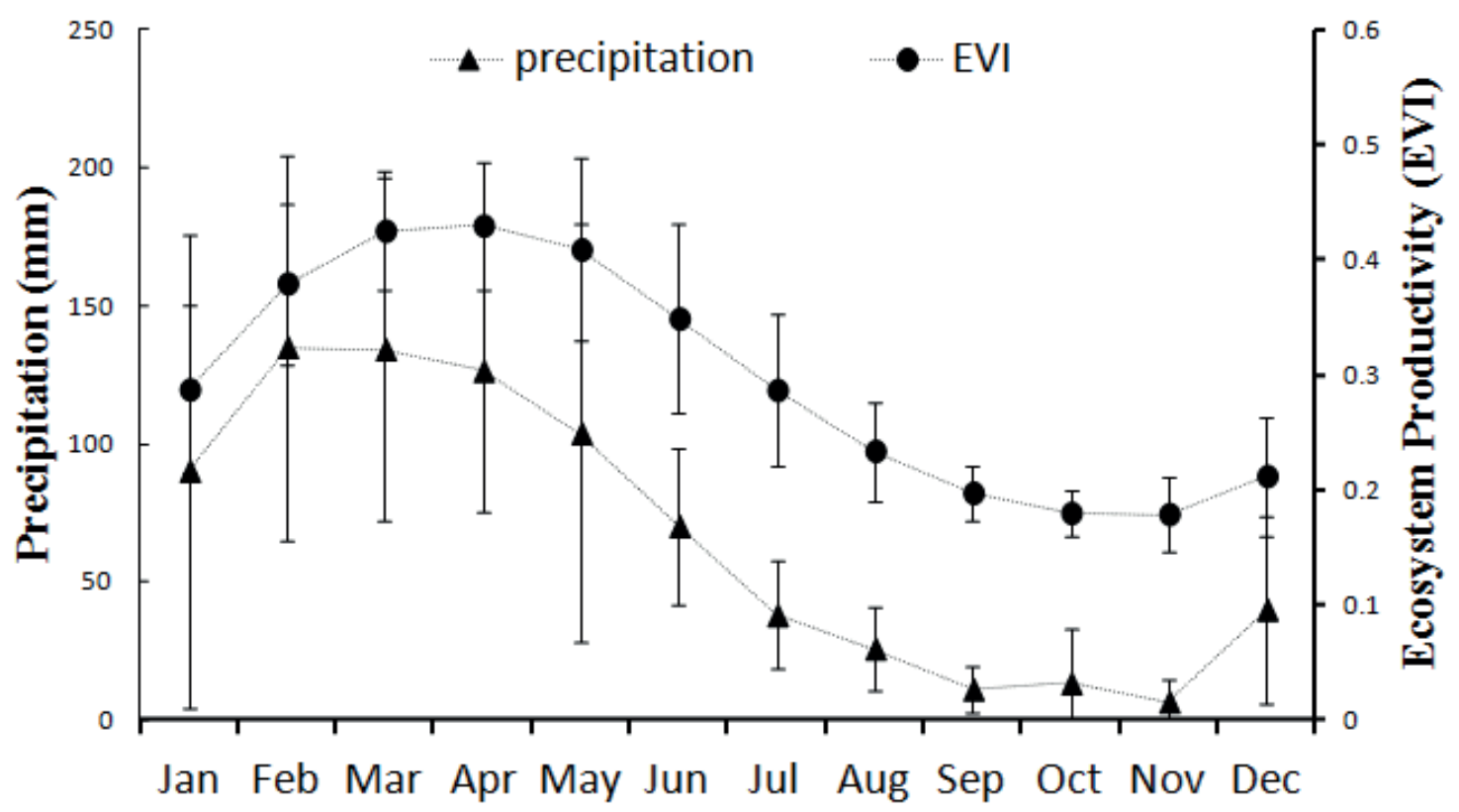

Figure 2 - Average seasonal variation (2001-2012) for both rainfall and ecosystem productivity (Enhanced Vegetation Index [EVI] as proxy) in 40 Caatinga sites in Paraíba State, Brazil. 


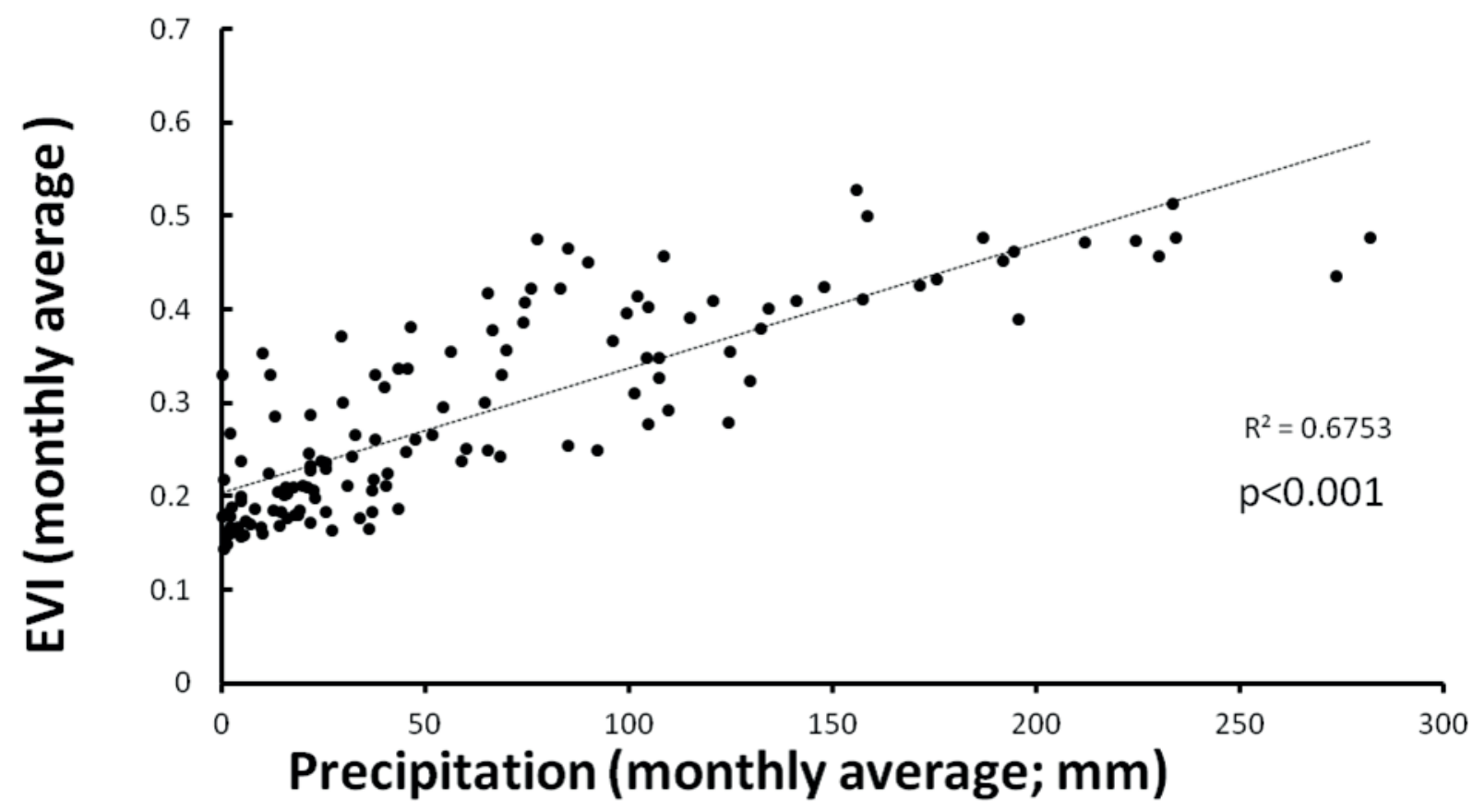

Figure 3 - Relationship between monthly average Enhanced Vegetation Index (EVI) and average rainfall for 40 Caatinga sites in Paraíba State, Brazil.

$\left(r^{2}=0.64\right.$ and $r^{2}=54$, respectively) for Paraíba state as a whole (including the Atlantic Rainforest).

\section{ANOMALIES}

The year 2009 had the greatest positive rainfall $(+39 \%)$ and EVI $(+16 \%)$ anomalies and 2012 the most negative anomalies (rainfall, - 65\%; EVI, $25 \%$ ) during the studied period (Figure 4a). This last rainfall characterizes a severe drought. When we correlated the rainfall anomaly with EVI anomaly (Figure $4 b$ ), we found a significant and strong relationship $\left(\mathrm{r}^{2}=0.86 ; \mathrm{p}<0.001\right)$.

Another marginal and weak, but ecologically important relationship, was also observed between the "rainfall x EVI" $r^{2}$ and the angular coefficient of the regression between both anomalies of rainfall and EVI $\left(\mathrm{r}^{2}=0.10, \mathrm{p}=0.057\right)$. This relationship indicates that during severe droughts, the influence of rainfall deficit is greater on the ecosystem functioning than during regular years.
The equation that describes the anomalies' relationship is $\mathrm{y}=0.38 \mathrm{x}+6.8 \mathrm{E}-18\left(\mathrm{r}^{2}=0.86\right.$; $\mathrm{n}=12 ; \mathrm{p}<0.0001)$. Since the linear coefficient was practically zero (6.8E-18), one can assume that the angular coefficient (slope) represents the almost exact percentage of increase in $\mathrm{Y}$, for each increase in X. Therefore, ecosystem productivity anomaly (expressed as EVI anomaly) is only $38 \%$ of the rainfall anomaly. If we apply the $38 \%$ decrease (slope for the anomalies relationship) in EVI for a $65 \%$ decrease in rainfall, for all 40 sites, the average annual EVI drops to $0.18 \pm 0.03$; which is more typical of semi-desert perennial grasslands and desert shrublands (Huete et al. 2002).

Our results suggest that if severe droughts become more frequent in the next decades, or even become the mode, not the exception (as projected by A2 scenarios of IPPC; Marengo et al. 2009), ecosystem productivity may be reduced from 25 to $38 \%$, or even more (we do not have data on the effect of subsequent severe droughts on EVI). Such 


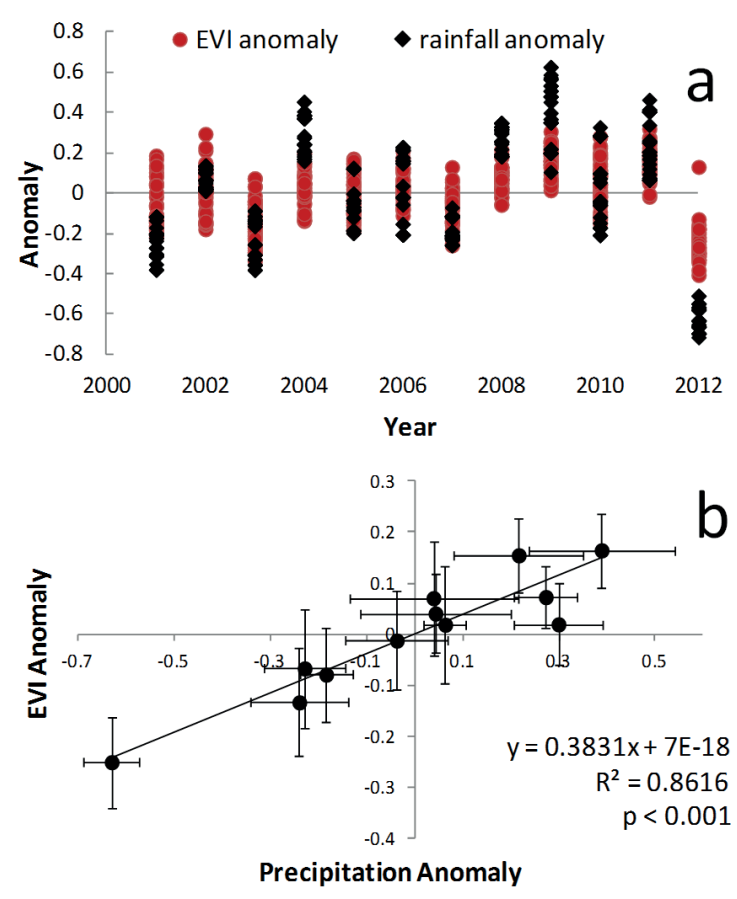

Figure 4 - a: Interannual anomalies for rainfall and Enhanced Vegetation Index (EVI), from 2001 to 2012, in 40 Caatinga sites, in Paraíba state, Brazil. b: Correlation between rainfall anomaly and EVI anomaly for the 12-year study period.

a reduction certainly will diminish the amount of food, wood and fodder availability for local people and livestock. Such trend could cause ecosystem disruption and drive the landscape to a new mode of stability, to an even more xeric ecosystem, in this case probably a desert. In such a scenario, the number of environmentally displaced people could be enormous, with serious impacts in coastal cities.

\section{CONCLUSIONS}

We have shown, with a very simplistic twodimensional approach, that about 50\% (from local average $47 \%$ to landscape level $68 \%$ ) of Caatinga vegetation productivity in the semiarid area of Paraíba state is correlated to rainfall variability. Rainfall anomalies explain more than $80 \%$ of ecosystem productivity anomalies (EVI as a proxy), although the vegetation amplitude anomalies is narrower than rainfall. These strong and significant relationships are important signs of how a decrease in rainfall could impact or even disrupt the predominant type of vegetation in the Brazilian semiarid region, under a possible future climate change scenario.

\section{REFERENCES}

ANDERSON LO, MALHI Y, ARAGÃO LE, LADLE R, ARAI E, BARBIER N AND PHILLIPS O. 2010. Remote sensing detection of droughts in Amazonian forest canopies. New Phytol 187(3): 733-750.

ARZ HW, PATZOLD J AND WEFER G. 1998. Correlated millennial-scale changes in surface hydrography and terrigenous sediment yield inferred from Last-Glacial marine deposits off northeastern Brazil. Quaternary Res 50: 157-166.

AULER AS AND SMART PL. 2001. Late Quaternary paleoclimate in semiarid northeastern Brazil from U-series dating of travertine and water-table speleothems. Quaternary Res 55: 159-167.

BARBOSA HA, HUETE AR and BAETHGEN WE. 2006. A 20-year study of NDVI variability over the Northeast Region of Brazil. J Arid Environ 67(2): 288-307.

BECERRA JAB, CARVALHO S AND OMETTO JPHB. 2015. Relação das sazonalidades da precipitação e da vegetação no bioma caatinga: abordagem multitemporal. Anais XVII Simpósio Brasileiro de Sensoriamento Remoto - SBSR, João Pessoa-PB, Brasil, 25 a 29 de abril de 2015, INPE, p. 6668-6674.

CAMPOS GEP ET AL. 2013. Ecosystem resilience despite large-scale altered hydroclimatic conditions. Nature 494: 349-352.

DONOHUE RJ, RODERICK ML, MCVICAR TR AND FARQUHAR GD. 2013. $\mathrm{CO}_{2}$ fertilization has increased maximum foliage cover across the globe's warm, arid environments. Geophys Res Lett 40: 3031-3035.

ERASMI S, SCHUCKNECHT A, BARBOSA MP AND MATSCHULLAT J. 2014. Vegetation greenness in northeastern Brazil and its relation to ENSO warm events. Remote Sens 6(4): 3041-3058.

FREITAS RD, ARAI E, ADAMI M, FERREIRA AS, SATO FY, SHIMABUKURO YE AND RUDORFF BFT. 2011. Virtual laboratory of remote sensing time series: visualization of MODIS EVI2 data set over South America. J Comp Int Sci 2(1) :57-68.

HUETE A, DIDAN K, MIURA T, RODRIGUEZ EP, GAO X AND FERREIRA LG. 2002. Overview of the radiometric and biophysical performance of the MODIS vegetation indices. Remote Sens Environ 83(1): 195-213.

INSA. 2012. http://livroaberto.ibict.br/bitstream/1/941/2/ INSA.pdf. Accessed in June, 2016. 
JIANG Z, HUETE AR, DIDAN K AND MIURA T. 2008. Development of a two-band enhanced vegetation index without a blue band. Remote Sens Environ 112(10): 38333845.

MALHI Y, ROBERTS JT, BETTS RA, KILLEEN TJ, LI W AND NOBRE CA. 2008. Climate change, deforestation, and the fate of the Amazon. Science 319(5860): 169-172.

MARENGO JA, JONES R, ALVES LM AND VALVERDE MC. 2009. Future change of temperature and rainfall extremes in South America as derived from the PRECIS regional climate modeling system. Int J Climatol: 29(15): 2241-2255.

NOVAES RLM, FELIX S AND SOUZA RF. 2013. Save Caatinga from drought disaster. Nature 498(13): 170.

PEREIRA MPS, JUSTINO F, MALHADO ACM, BARBOSA H AND MARENGO J. 2014. The influence of oceanic basins on drought and ecosystem dynamics in Northeast Brazil. Environ Res Lett 9(12): 124013.

PINHEIRO ARE, METSELAAR K, JONG VAN LIE Q AND ARAÚJO JC. 2016. Importance of soil-water to the Caatinga biome, Brazil. Ecohydrology 9: 1313-1327.

R DEVELOPMENT CORE TEAM. 2008. R: A language and environment for statistical computing. R Foundation for Statistical Computing, Vienna, Austria. Available at: http:// www.Rproject.org. Accessed 15/04/2009.

RAN Y, LI X, SUN R, KLJUN N, ZHANG L, WANG X AND ZHU G. 2016. Spatial representativeness and uncertainty of eddy covariance carbon flux measurements for upscaling net ecosystem productivity to the grid scale. Agr For Meteorol 230: 114-127.
SAATCHI S, ASEFI-NAJAFABADY S, MALHI Y, ARAGÃO LE, ANDERSON LO, MYNENI RB AND NEMANI R. 2013. Persistent effects of a severe drought on Amazonian forest canopy. P Natl Acad Sci 110(2): 565-570.

SCHUCKNECHT A, MATSCHULLAT J AND ERASMI S. 2012. Spatial and temporal variability of vegetation status in Paraíba, Northeastern Brazil. In 2012 IEEE International Geoscience and Remote Sensing Symposium, p. 32-35.

WAGLE P, XIAO X, TORN MS, COOK D, MATAMALA R, FISCHER ML AND BIRADAR C. 2014. Sensitivity of vegetation indices and gross primary production of tallgrass prairie to severe drought. Remote Sens Environ 152: $1-14$

WANG X, AULER AS, EDWARDS RL, CHENG H, CRISTALLI PS, SMART PL AND SHEN CC. 2004. Wet periods in northeastern Brazil over the past 210 kyr linked to distant climate anomalies. Nature 432(7018): 740-743.

WELTZIN JF, LOIK ME, SCHWINNING S, WILLIAMS DG, FAY PA, HADDAD BM AND POCKMAN WT. 2003. Assessing the response of terrestrial ecosystems to potential changes in rainfall. Bioscience 53(10): 941-952.

XUANLONG MA ET AL. 2013. Spatial patterns and temporal dynamics in savanna vegetation phenology across the north australian tropical transect. Remote Sens Environ 139: $97-115$.

\section{SUPPLEMENTARY MATERIAL}

Table SI 